\section{PAPER CALENDER}

\section{THE UNIVERSITY OF BATH}

The University of Bath (England) announces two conferences. The first conference, "Political Representations of Forced Migrations," is September 2002. The second conference, "Literary Representations of Forced Migrations," is April 2003. Comprehensive outlines of papers and biographical abstracts of applicants are due November 3, 2000. Completed papers for conference one are due August 2, 2002, and January 31, 2003 for conference two. Please send proposals and abstracts to: Stefan Wolf, Email: S.Wolff@bath.ac.uk.

\section{BERKSHIRE CONFERENCE}

The 12th Berkshire Conference on the History of Women is June 6-9, 2002 at the University of Connecticut-Storrs. The theme is "Local Knowledge - Global Knowledge." The program committee welcomes proposals that explore the relationship between local knowledge, global knowledge, the history of women, and the emergence of notions of gender across time and culture. Proposals are due December 15, 2000. For more information visit: Web: www.berksconference.org.

\section{INTERNATIONAL ANTHOLOGY ON GENDER}

Proposals are being solicited for an International Anthology on Gender, Gender Relations, and Women's Activism in Mining Communities. The editors are particularly interested in submissions about Latin American, Asian, and African communities, as well as relevant submissions from scholars working on North American, European, and East European topics. The submission deadline is March 1, 2001. For further information contact: Dr. Jaclyn Gier Viskovatoff, Department of History, Spotts World Culture Blvd. 212J, University of Pennsylvania-Slippery Rock, Slippery Rock, PA 16057; Tel: (724) 738-2409; Fax: (724) 738-4762; Email: jaci001@attglobal.net or Dr. Laurie Mercier, Washington State University-Vancouver, 14204 NE Salmon Creek Ave, Vancouver, WA 98686; Tel: (360) 546-9646; Fax: (360) 546 - 9036; Email: mercier@vancouver.wsu.edu.

\section{CINEMACTION}

The French Journal Cinemaction is seeking papers for an issue on African cinema since the end of 70 's and continuing to
1980. Papers are being sought that would develop the idea of a historical, ideological, or practical transition in cinemas made in Black Africa since 1980. Articles that address African cinema in Lusophone areas and in Middle Africa are also of interest. The project is also opened to any text that would treat a transition in the history of the cinema of Africa or the nomadism of the African filmmakers. For further information contact: Dr. Samuel Lelievre, 9 rue Andre Trasbot, 35000 Rennes, France; Tel:(33) (0)2 $9967 \quad 05$ 43; Email: dorissamuel@wanadoo.fr.

\section{THE MCNEIL CENTER FOR EARLY AMERICAN STUDIES}

The McNeil Center for Early American Studies invites paper proposals for a conference entitled "New World Orders: Violence, Sanction, and Authority in the Early Modern Americas, 1500-1825." The conference is October 19-20, 2001 in Philadelphia, PA. The conference will explore the wide variety of extralegal means by which social order was maintained in the early Americas. Proposals should include a brief c.v. and a three-tofive page prospectus explaining the substance of the proposed paper, the sources to be used, and the topic's relationship to the conference theme. Initial proposals must be post marked by December 1 , 2000. Those invited to participate in the conference will be asked to submit papers of approximately 30 pages in length by August 15, 2001. For further information and to submit direct questions contact: Email:smolensk@sas.upenn.eduortom.hu mphrey@csuohio.edu; Website: www.mceas.org.

\section{PATHWAYS TO AFRICA'S PAST}

"Pathways to Africa's Past " is the theme of a three-day conference scheduled for March 30 - April 1, 2001 in Austin, Texas. The theme is centered around using diverse methods and sources to recreate and narrate African history and society from different perspectives The aim of the conference is to provide a space for Africanists that are still in the forefront of incorporating new ideas into the historical method by drawing on ecological, medical, archaeological, literary, linguistic, and anthropological materials. Graduate students and advanced undergraduates are encouraged to participate, both to present papers and to participate in the workshop. Presenters include Paul Lovejoy and David Henige. For further information contact:
Toyin Falola; Email:toyin.falola@mail.utex as.edu;or Christian Jennings; Email:xianjen@mail.utexas.edu.

\section{CANADIAN ASSOCIATION OF AFRICAN STUDIES}

The Canadian Association of African Studies (CAAS) presents its annual conference May 27-30, 2001. The theme is "Africa: Between the Demons of the Past and the Promises of the Future." The CAAS conference takes place as part of Canada's annual spring academic spectacular. Once known affectionately as the "Learneds," the Congress of Social Sciences and Humanities brings together over a ten day period more than 50 academic associations. This makes possible a large book exhibit and a range of artistic and intellectual activities. Submission of proposals for panels and individual papers are welcomed. Proposals are due January 15, 2001. Send proposals to: Sean Hawkins, Department of History, University of Toronto, 100 St. George St, Toronto M5S 3G3,Ontario; Email:sean.hawkins@utoronto.ca; Website: www.caas.ca.

\section{COLLEGE ART ASSOCIATION}

The 9th Annual Conference of the College Art Association (CAA) is February 20 -24, 2002 at the Philadelphia Marriott Hotel and the Philadelphia Convention Center, in Philadelphia, PA. As an organization affiliated with CAA, the Arts Council of the African Studies Association is invited to submit an affiliated society-sponsored session proposals for consideration by the Annual Conference Committee. Each CAA affiliated society may submit one proposal for a two and a half hour panel that follows the call for proposals and the submission guidelines published in the May 2000 CAA news. For further information contact: Martha G. Anderson; Email : fanderson@alfred.edu.

\section{WAGENINGEN UNIVERSITY AND RESEARCH CENTRE AND THE UN FOOD AND AGRICULTURE ORGANISA- TION}

Wageningen University and Research Centre (WUR) and the UN Food and Agriculture Organisation (FAO), together with three Dutch research schools, is organizing an international conference in May 2001 in Wageningen, the Netherlands. The theme is "Livelihood, Savings and Debt in a Changing World: D e veloping Anthropological and Sociological Perspectives." The aim is to create a better 
understanding of savings and credit behavior as part of a different and changing relational and broader contexts, based on new social-scientific challenges, problem statements and insights. For registration and submission information visit: Website:www.sls.wau.nl/law/livelihoodsavingsdebt; and www.sls.wau.nl/livelihoodsavingsdebt.

\section{MEETING CALENDER}

\section{THE AMERICAN ASSOCIATION FOR HISTORY AND COMPUTING}

The American Association for History and Computing presents its 2001 Annual Meeting. The theme is: "Moving Clio into the New Millennium:Interaction, Visualization, Digitization, and Collaboration." University and college instructors, K-12 teachers, librarians, publishers, editors, archivists, interpreters, students, software developers, and all other history professionals are encouraged to participate. For further information contact: Dennis Trinkle, Executive Director, American Association for History and Computing, Department of History, DePauw University, Greencastle, IN 46135; Email: dennis.trinkle@theaahc.org;orKen Dvorak, Secretary/Treasurer, American Association for History and Computing, 17250 Logans Run,Battle Creek, Michigan, 49014;:Email:dvorakkr@aol.com; Website:theaahc.org.

\section{UNIVERSITY OF MUMBAI}

The Center for African Studies, University of Mumbai (Bombay) is planning a three day international seminar in February 2001. The theme is "Indian Ocean Island States and the Littoral: Conflict and Cooperation." The seminar is designed to cover developments in the area geographically ranging from Cape of Good Hope to Indonesian archipelago within a global perspective. For further information contact: V.S. Sheth, Director of The Center for African Studies, University of Mumbai (Bombay), Bombay, India; Fax: 0091-226526893.

\section{LIBERIAN STUDIES ASSOCIATION}

The 33rd Annual Meeting of the Liberian Studies Association is May 13 - 152001 in Tel Aviv University, Israel. The theme is "Liberia, Africa and the International Community." For more information contact: ProfYekutielGershoni, Department of Middle Eastern and African History, Tel Aviv University, Tel Aviv 69978, Israel; Email: gygygy@post.tau.ac.il.

\section{EMPLOYMENT OPPORTUNITIES}

\section{RESEARCH ASSISTANT}

The Metropolitan Museum of Art is seeking a part-time Research Assistant to assist with research centering on the permanent collections and special exhibitions of arts of Africa, Oceania and the Americas, both inside the Museum and for outgoing loans. The candidate will supervise the cataloguing of African collections in both card and electronic form. Candidates are required to have an M.A. degree in art history with specialization in African art. Reading knowledge of French is necessary, German helpful. For further information and to submit application contact: The Metropolitan Museum of Art, Human Resources, Box TS AAOA, 1000 Fifth Avenue, New York, NY 10028.

\section{EXECUTIVE SECRETARY}

The Council for the Development of Social Science Research in Africa (CODESRIA), based in Dakar, Senegal, invites applications from African Social Science scholars for the position of Executive Secretary. The Executive Secretary is responsible for coordinating the writing of proposals for various programs, funding requests and research reports; providing intellectual leadership to research networks activities; promoting the establishment of professional associations; and organizing and facilitating scientific round tables, meetings and conferences in Africa. The candidate is required to have experience in research formulation, guidance, coordination and research reporting, have knowledge of CODESRIA and/or similar research organizations, possess management and administrative experience in similar research organizations with experience and credibility in fund-raising. A working knowledge (oral and written) of both French and English is necessary. Candidates should submit an application letter, a detailed curriculum vitae including training and professional experience, three reference letters from people who know the applicant's work (including at least two resident in countries other than those of the applicants), one copy of three or four of applicant's own publications. Reference letters should be sealed and sent directly to CODESRIA. The application deadline is November 15, 2000. If interested, send correspondence labeled "APPLICATION" to: The President of the Executive Committee, CODESRIA, BP 3304, Dakar, Senegal.
ASSISTANT PROFESSOR

The Women's Studies Department at the University of California-Berkeley invites applicants for a full-time Assistant Professor in Gender and Political Economy in a Global Context. The position is a tenure-track position beginning July $\mathbf{1}$, 2001. Send a cover letter, c.v., a short writing sample, and three letters of recommendation by November 1, 2000 to: Caren Kaplan, Chair, Department of Women's Studies, 3326 Dwinelle \#1070 ,University of California-Berkeley, Berkeley, CA 947201070; Tel: (510) 642-8513.

\section{ASSISTANT PROFESSOR}

The Department of Art History at the University of California-Santa Cruz, invites applications for a tenure-track position as Assistant Professor specializing in study of the visual cultures of Africa and/or the African Diaspora. The position is available July 1, 2001. Candidates with Ph.D. or advanced $\mathrm{Ph} . \mathrm{D}$. candidate in a relevant field of study are preferred. Letters of application should address scholarly background, current work, and future research plans. Application materials consist a writing sample; descriptions of three courses; list of three references from whom the applicant has requested confidential letters of recommendation. Please submit all materials by December 15, 2000 to: Africa Search Committee Department of Art History, Porter Faculty Services, University of California, $1156 \mathrm{High}$ Street Santa Cruz,CA 95064;.Website: www2.ucsc.edu lahr/academic.html.

\section{ASSISTANT PROFESSOR}

The College of Arts and Sciences at the University of San Francisco invites applications for a Assistant Professor tenure-track position in Anthropology, Communication Studies, Fine and Performing Arts, History, Media Studies, S o c i ology, or Theology/Religious Studies with speciality in African studies. The position is available in the Fall 2001, pending approval and funding. Teaching responsibilities may include lower and upper division courses centered on Africa as well as in the candidate's area of specialization. The candidate is expected to have university teaching experience, evidence of a strong commitment to teaching, evidence of scholarship, and an earned doctorate by Fall 2001. Applicants are asked to submit a letter of application, curriculum vitae, graduate transcripts, copies of recent publications, statement of teaching philosophy, evidence of teaching ability including copies of complete teaching evaluations, and three let- 